\title{
Basic Principles of Tourist Services Market Segmentation
}

Submitted 21/02/19, $1^{\text {st }}$ revision 15/03/19, accepted 08/04/19

\author{
N.E. Goryushkina ${ }^{1}$, T.V. Gaifutdinova ${ }^{2}$, E.V. Logvina ${ }^{3}$, \\ A.G. Redkin ${ }^{4}$, V.V. Kudryavtsev ${ }^{5}$, Y.N. Shol ${ }^{6}$
}

\begin{abstract}
:
Purpose: The main aim of the article is to identify the principles of tourist services for an effective segmentation using data from official primary and secondary bases.

Design/Methodology/Approach: The authors have justified the importance of dividing potential tourists into homogenous groups (segments) in accordance with the general characteristic features of their demand. In that manner, according to the authors, a tourist product is provided with its target orientation as, on the one hand, it cannot meet the requirements of all tourists and on the other hand, a tourist company can concentrate their marketing efforts on the most perspective market segments rather than dissipate them.

Findings: A definition of 'tourist service' has been made and its characteristic features have been described as well. Stages of segmenting starting from selection of criteria to determination of methods of work with the chosen segment have been identified and described.

Practical implications: Identification of segments in tourism is mainly made based on their geographical, demographical, socio-economic, psychographic, behavior characteristics or their combinations. On the other hand, the authors stress on the fact that there is no universal segmentation approach and therefore, potential tourists can be classified based on other characteristics.

Originality/Value: The conclusion that successful segmenting determines efficient operation of a tourist enterprise has been made.
\end{abstract}

Keywords: Tourism, Tourist Market, Tourist Service, Segmenting, Consumers, Segment, Demand.

JEL Classification: Q56, L83.

Paper type: Research article.

\footnotetext{
${ }^{1}$ Southwest State University, Kursk, Russia, gor046@yandex.ru

${ }^{2}$ Naberezhnye Chelny State Pedagogical University, Naberezhnye Chelny, Russia.

${ }^{3}$ V.I. Vernadsky Crimean Federal University, Simferopol, Russia.

${ }^{4}$ Altai state University, Barnaul, Russia.

${ }^{5}$ K.G. Razumovsky Moscow State University of technologies and management (the First Cossack University), Moscow, Russia.

${ }^{6}$ Kuban State Agrarian University named after I.T. Trubilin, Krasnodar, Russia.
} 


\section{Introduction}

Presently, development of tourism has become an important source of income for many regions in Russia (Kozhokin \& Zherelina, 2017). The number of tourist companies is steadily growing every year and 13,580 tourist enterprises were registered as of the beginning of 2018 (Selected Data of Tourist Companies' Activity in 2009-2017). In connection with that competition the tourist services market is becoming tougher and it has turned into the fight of strategies rather than that of the resources. Successful competitiveness of a tourist company depends on whether it will be able to develop a service which will bring significant profit (Yamova et al., 2018).

Meanwhile, each service consumer has their own habits, tastes, financial opportunities and desires. Hence, the more sophisticated the consumption is, the more efforts one must invest to develop a new service which can meet expectations of a great number of consumers. That is the key reason for a tourist company's necessity to identify a group of consumers with similar characteristics who are characterized with homogenous demand. Such groups are called market segments and the process of their identification is called segmentation (Malarev et al., 2018; Lavrenko et al., 2019; Korolyov and Lavrenko, 2017; Trufanova and Lavrenko, 2016; Nefedov, 2018). The article describes the basics of the tourist market segmentation.

We shall admit that a great number of works both by Russian and foreign authors have been devoted to study different aspects of marketing (Nikolaeva et al., 2018; Safieva et al., 2017; Prischepa et al., 2018a; Prischepa et al., 2018b). However, the specifics of the tourism market require conducting specialist researches including the ones in such an important sphere as segmenting of tourist services. The list of the most competent contemporary authors who have justified the necessity of dividing potential tourists into segments includes A.P. Durovich (2008), T.B. Klimova (2018), V.S. Yankevich (2005), E.V. Sarafanova and A.V. Yatsuk (2009), T.I. Klimenko and A.O. Ovcharov (2016). Regardless the great number of works on the issue the basic principles of tourist services market segmenting require systematization and more detailed description.

\section{Methodology}

The methodological basis of the article includes the works of both national and foreign scientists devoted to the specifics of customer behavior in the tourist services market. Also, the data from the Federal Agency for Tourism (Russia) and World Tourism Organization has been used for writing the article. Systematic, abstractlylogical and functional approaches as well as deduction, induction analysis and synthesis methods have been used by the authors. Apart from the mentioned above methods marketing research tools, which enabled to describe the basics of tourist services market segmenting, have been studied. 


\section{Results}

We will assume that a tourist company is an independently acting economic entity which was established in order to receive income due to execution of works or rendering services to meet tourists' (sightseers) requirements. Tourist companies are divided into primary, secondary and tertiary. The primary companies are focused exclusively on generating profit from tourism. The secondary tourist companies take a significant share of tourist's demand and interest structure formation as well as in development of the tourist product (Movchan and Yakovleva, 2017; Kuznetsov and Suprun, 2017; Kuznetsov et al., 2017; Malarev et al., 2019; Koptev and Kopteva, 2017; Koptev and Kopteva, 2018). Rendering tourist services is only one direction of their commercial activities and sometimes even the secondary one. The list of these companies includes theme parks, transportation companies, etc. The tertiary tourist companies provide tourists with goods and services and to some extend depend on tourism. Insurance companies, banks, exchange offices, souvenir shops, renting companies, publishing houses specializing on publishing tourist materials constitute the scope of these enterprises.

Tourist companies produce a tourist product (services). Federal Law issued 24.11.1996 No 132-FL on the Fundamental Principles of Tourist Activities in the Russian Federation (in edition of Federal Law as of 03.05.2012 No 47) states that a tourist product is "a complex of services targeted on transfer and accommodation rendered at the blanket price (regardless inclusion of the cost of excursion and/or any other services into the total price) according to the agreement on sale of a tourist product." A tourist product consists of the following parts: main services, additional services and related services. The main complex of services is the compulsory element of any tourist package regardless its target audience. Additional services are significant elements of the package including the services which can be rendered to a customer for extra pay (Sultanova and Mardashov, 2016; Korobov and Podoprigora, 2018; Podoprigora and Korobov, 2017; Raupov and Korobov, 2018). The range of additional services includes providing with tourist equipment, national souvenirs and tourist insignia, currency exchange, loans, access to the Internet, postal and telegraph services, providing with a safe deposit box, etc. Despite their significant difference, they all have the following four characteristic features in common: impalpability; inseparability of their production and consumption; changeability of quality; inability to be stored.

A tourist service evaluation is made by consumers influenced by their emotional conditions depending on a great number of factors, namely specifics of upbringing, age, cultural traditions of the people which the guest represents, their understanding of comfort, habits, health or psychological conditions at the time of receiving the service, etc. Nevertheless, economists have not been keen on studying of tourist services consumers' behavior (Tananykhin and Khusainov, 2016; Sharifov and Mardashov, 2018; Ovcharenko et al., 2017; Vasiliev and Mardashov, 2017). They mainly used the definitions of consumer preferences and consumer satisfaction. 
Their list of consumer preferences constant properties includes the following (Figure 1):

Figure 1. List of consumer preferences constant properties

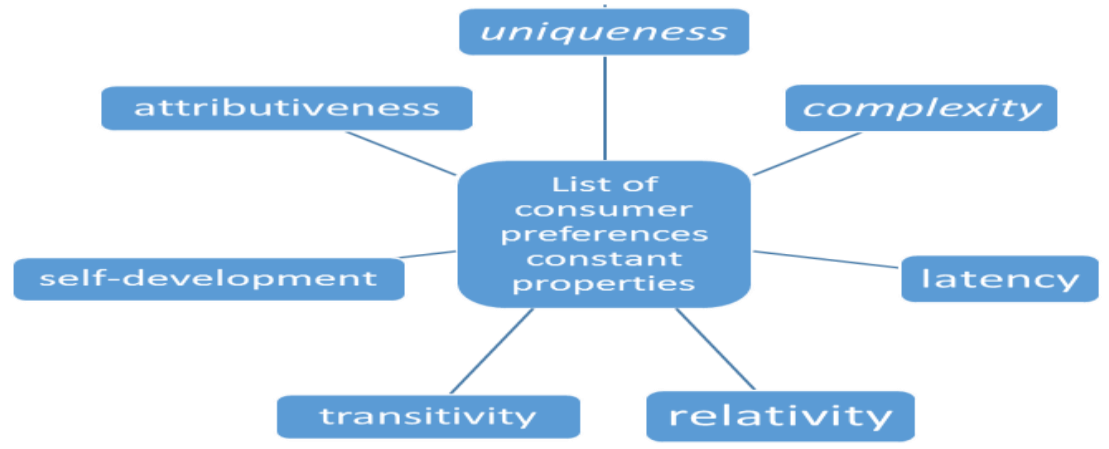

1) Complexity, i.e., formation of the entire complex of interlinked, interdependent and mutually influencing consumer preferences.

2) Permanency, i.e., inconsistency of preferences existence in consumer's psychology regardless the external conditions. The preferences always exist in consciousness and are not connected with our purchase of goods.

3) Attributiveness, i.e., correspondence of each preference to some individual properties, elements and characteristics of the goods (its attributes).

4) Self-development, i.e., development of preferences, detailed reflection, identification of attributes while deciding.

5) Uniqueness, i.e., individuality and specific features of complex of preferences.

6) Transitivity, i.e., an ability of a certain preference to turn into another one smoothly or abruptly, to be replaced with a third one, etc.

7) Relativity, i.e., deliberate or unconscious comparison of the preferred goods with other products.

8) Latency, i.e., concealment of preferences and their exhibition only now of interaction with a product or during communication concerning it.

As a single tourist company is unable to cover the entire market, its segmenting will allow to identify the area to concentrate their efforts on and to attract customers (How Travel Package is Formed, 2019). Our understanding of a market segment includes specifically identified group of customers with similar preferences and equal reaction to a product or to a service (Tananykhin and Saychenko, 2017; Tananykhin and Shagiakhmetov, 2016; Tcvetkov et al., 2018; Shagiakhmetov et al., 2018). Having made segmentation a tourist company evaluates attractiveness of each market segment based on a set of criteria including a segment capacity, accessibility of the segment for a tourist company, prospectively and profitability. An addressable market is the most suitable and profitable for a tourist company market segment (or a group of segments), their market activity targets at (Nefyodova, 2017; p. 142). 
Each specialist of the tourist business should master the basics of tourist services segmenting (Goryushkina, 2017; Goryushkina, 2015; Aleksandrova and Talovina, 2017; Gurman et al., 2017; Korchevenkov and Aleksandrova, 2018). As a rule, the process of segmenting consists of four stages. The first stage implies choosing criteria of segmentation. Choosing of the segmentation strategy (aggregated, concentrated or differentiated one) is made at the second stage. The third stage incudes selection of segmentation methods (grouping, functional maps and segmentation grids development, etc.). Methods of dealing with different segments are developed at the fourth stage.

It goes without saying, that a universal approach to segmentation does not exist. Hence, segmentation is made based on different properties (one or several of them at the same time). The most typical segmentation is the one based on the following five properties: geographical, demographical, socio-economic, psychographic and behavioral as well as their combinations. In case of making segmentation based on the geographical property, groups of tourists are identified according to their place of residence including the country, the area, the province, the district, the city, etc. Dividing the market into the groups of consumers according to the following properties including their age, sex, family size, family life cycle, occupation, education, religion, race and nationality is called demographic segmentation (Polyakova et al., 2018; 2019; Takhumova et al., 2018; Sozinova et al., 2017).

The United Nations World Tourism Organization (UNWTO) was established in 1975 as a successor of the International Union of Official Tourist Publicity Organizations. According to UNWTO all consumers of the tourist product are divided into different groups according to the age including the children aged 0-14 who travel with their parents who receive many tourist services at discount prices; youth aged 15-24 who travel without their parents and have limited funds; young people aged 25-44 who mainly travel with their families or children and their tourist behavior is totally determined by their children's needs; middle-aged people (4560 -year-old ones) who remain economically active but unlike people from the previous group they mainly travel without their children who have left their house having matured; and the third-aged tourists (aged 60+), the group of tourists whose number is growing every year and they travel year-round (Resilience of tourism development, 2019).

Each of these age groups is characterized with their well-defined type of behavior and their own tourist priorities. Socio-economic segmentation considers the level of income, social status, occupation (profession) and educational level of the tourist services consumers (Korableva et al., 2018; Poltarykhin et al., 2018; Ivanova et al., 2018; Aleksandrova et al., 2015; Nikolaeva et al., 2018; Tananykhin et al., 2018). Four segments of tourist services consumers can be identified based on the combination of two properties, levels of income and education. The first segment includes people with average or even low level of income. The main goal of their travelling is going to the seaside. The tourists who belong to that category do not 
have enough funds, they are rather sensible to services prices and at the same time they are extremely severe upon their quality.

Their main principle includes receiving maximum of possible services for their modest funds. They show their interest in entertainment, nightclubs, bars and discos. Although a cognitive goal is not the main stimulus of their travelling, they frequently show their interest in different excursions which can make their sharing of experience with their friends and relatives more prestigious. Souvenirs are the proof of the trip undertaken (Aleksandrova et al., 2017; Aleksandrova et al., 2019; Aleksandrova and Afanasova, 2019). That segment is the largest in terms of the international tourist exchange. The second segment of the tourist services market covers the residents with above average level of income. As a rule, these tourists have a university or a college degree. Although the main reason for their travelling is recreation, the time off should include sports, excursions, theatres and concerts. Besides, those who are fond of long-distance travelling are also a part of the segment. The third segment covers tourists with high level of income. As most of them have a university or college degree they prefer to make informative trips trying to gain a new experience. Long, two-or three-week trips are what representatives of the segment need. The tourists are interested in purchasing souvenirs which can be rather expensive justifying their extended and exotic trips. Those who constitute the fourth segment are highly-educated people interested in studying the nature, the culture, the way of life, customs and habits of the local population.

Although representatives of the fourth segment differ by age and level of income, they are ready to spend significant sums of money for travelling and frequently do it at the expense of their savings. The goals of the trips may vary but their desire to extend their personal experience is what they have in common. In case the goal of a trip is acquaintance with life of the local people, the tourists spend some time living among the locals, having their meal and in some cases, they can also try to master the local crafts showing great interest to the folklore (Achaeva et al., 2018; Achaeva et al., 2016, Achayeva et al., 2015; Melnikov et al., 2018; Kayumova et al., 2019). Although a few tourists belong to the segment, it has tended to grow in number of late. The following five characteristics are identified while making psychographic segmentation including inclination to changes, readiness to take a risk, degree of conservatism, requirements to comfort and intellectual level of tourism requests. In case of making behavioral segmentation in tourism, this process is based on benefit segmentation, i.e., business, entertainment, search of new acquaintances and an opportunity to put into effect their creative potential; segmentation according to the degree of consumers' devotion to tourist centres or districts; and segmentation based on the level of consuming intensity (Nefedov and Klepikov, 2018; Prischepa and Grokhotov, 2018; Solnyshkina et al., 2014; Solnyshkina et al., 2016). However, apart from the mentioned above criteria, different approaches can be taken to make the segmentation. 
For instance, German scientist H. Hahn has identified six main types of tourists where each group is titled according to the initial letter of its corresponding word in German, i.e., S, F, W-1, W-2, A and B types. S type of tourists (originates from German Sonne, Sand, See - Sun, sand beach and sea) includes typical holidaymakers who prefer a passive type of spending vacation at sea resorts, calmness and comfort (Podoprigora and Saychenko, 2017; Podoprigora et al., 2016). These persons avoid hectic way of spending their vacation although they don't mind communicating with nice and pleasant people. People of $\mathrm{F}$ type (originates from German Ferne und Flirtorientierter Erlebnisurlauber) are holiday-makers who prefer long-distance trips, a kaleidoscope of experiences and flirtation. They will spend their vacation only in the areas full of different events as slow and thoroughly warming on a beach alone or with their family members is not what they desire.

These tourists' credo can be expressed as 'Society, Pleasure and Change of Experiences'. People of W-1 type (originates from German Wald- und Wanderorientiert- the one fond of forest walks and trips) are holiday-makers who are fond of active style of spending vacations. Physical outdoor activity regardless the weather conditions is their credo and these tourists try to stay in a good shape even during their vacations although they do not do sports professionally. W-2 type of tourists covers mainly athletes rather than amateurs who can endure extended, up to extreme, muscle loading.

The main criterion of holiday destination choosing for these people is the conditions to do their hobbies whereas the criterion of 'Landscape, Culture and History' is of a secondary importance for them. Tourists of A-type (originates from German Abenteure - adventure) belong to those who are fond of adventure. Risk, new experiences, trail of own abilities in unexpected situations and danger determine the choice of tourists of that type. On the contrary, tourists of B type (originates from German Bildung- und Besichtigung - education and sightseeing) are rather curious tourists (Podoprigora and Raupov, 2018; Raupov and Podoprigora, 2017; Prischepa et al., 2018c; Prischepa and Averyanova, 2017; Korobov and Raupov, 2017). This group is divided into three subgroups including experts who collect the places of interest they have visited; emotional fans of culture and nature; and specialists who enlarge their knowledge of certain areas of culture, history, art, etc.

Methods of observation, interviewing and polling, questionnaire, method of expert evaluations, ranging, multidimensional scaling as well as concentrated and disperse methods should be used to identify preferences of tourist services consumers. As importance of both recreation and tourism in the life of modern people is increasing and the structure of their needs is enlarging, segmentation of tourist demand applicability is becoming more important. A segment may be identified by combining several criteria and there can be several combinations of that sort. Each of these combinations should be analyzed in terms of its applicability to tourist company's business opportunities. 


\section{Conclusion}

Segmentation of tourist services market is one of the key elements of tourism marketing. It is necessary to conduct such segmentation to find out the target audience with the following successful selling of tourist services. Tourism industry determine a great number of consumers as potential buyers of tourist services and which means that their great number of needs and requests should be met. Usage of market segmentation triggers development of both tourist companies in certain areas along with strengthening of their competitiveness and improves efficiency of meeting consumer needs restricted with limitations set by the chosen segment.

\section{References:}

Achaeva, M.S., Pospelov, S.A., Pospelova, N.V. \& Subbotina, N.S. 2016. Toponymic picture of scotland: Thesaurus approach. Journal of Organizational Culture, Communications and Conflict, 20 (Special Issue), 121-127.

Achaeva, M., Daurova, A., Pospelova, N. \& Borysov, V. 2018. Intercultural education in the system of training future teachers. Journal of Social Studies Education Research, 9(3), 261-281. doi:10.17499/jsser.48690.

Achayeva, M.S., Pospelova, N.V. \& Subbotina, N.S. 2015. Derivational slots of parametric adjectives: Cognitive aspect. Journal of Language and Literature, 6(3), 171-174, doi:10.7813/j1l.2015/6-3/39.

Aleksandrova, T.N., Nikolaeva, N., Romashev, A. 2015. An experimental and theoretical approach to the assessment of the specific surface of apatite-nepheline ore in the process of grinding. International Multidisciplinary Scientific GeoConference Surveying Geology and Mining Ecology Management, SGEM, 577-583.

Aleksandrova, T.N. \& Talovina, I.V. 2017. Platinum-group metals in residual soils and potential efficiency of their processing in gravity concentrators. Journal of Mining Science, 53(3), 553-558. doi:10.1134/S106273911703250X.

Aleksandrova, T., Romanenko, S. \& Arastumian, K. 2017. Electrochemistry research of preparation slurry before intermediate flotation for sulphide-polimetallic ores. Paper presented at the International Multidisciplinary Scientific GeoConference Surveying Geology and Mining Ecology Management, SGEM, 17(11) 841-848, doi:10.5593/sgem2017/11/S04.107.

Aleksandrova, T., Romanenko, S. \& Arustamian, K. 2019. Research of slurry preparation before selective flotation for sulphide-polymetallic ores. Paper presented at the IMPC - 29th International Mineral Processing Congress, 2071-2078.

Aleksandrova, T.N. \& Afanasova, A.V. 2019. Fine-dispersed particles of noble metals in sulphide carbonaceous ores and its beneficiation prospects. Paper presented at the IMPC - 29th International Mineral Processing Congress, 2368-2376.

Durovich A.P. 2008. Marketing Research in Tourism. SPb.: Piter. 384 p Selected Data of Tourist Companies' Activity in 2009-2017. URL: https://www.russiatourism.ru.

Federal Law "On the Fundamental Principles of Tourist Activities in the Russian Federation". URL: http://www.consultant.ru/document/cons_doc_LAW_12462

Goryushkina N.E. 2017. Hotel Business: Issues Qualified Personnel Recruiting to Kursk Hotels. Actual Issues of Modern Area Studies. Digest of II National Scientific and Practical Conference. Kursk: YuZGU, 5-9.

Goryushkina N.E. 2015. Human Resources Is the Key: Educating of Professional Specialists 
for Tourism and Hospitality Industries in Southwest State University. Document Support of Organizational and Manufacturing Activities: Digest of Regional Scientific and Practical Conference. Kursk: YuZGU, 72-74.

Gurman, M.A., Aleksandrova, T.N. \& Shcherbak, L.I. 2017. Flotation of low-grade goldand carbon-bearing ore. Gornyi Zhurnal, (2), 70-74, doi:10.17580/gzh.2017.02.13.

How Travel Package is Formed. URL: https://www.russiatourism.ru.

Ivanova, V.N., Atyukova, O.K. \& Poltarykhin, A.L. 2018. Prerequisites of growth of investment and social attractiveness of the regions of russia within the framework of implementation of the public-private partnership projects. International Journal of Mechanical Engineering and Technology, 9(11), 2299-2305.

Klimova, T.B. 2018. Tourist Marketing. Belgorod: BelGU, 122 p.

Klimenko, T.I., Ovcharov, A.O. 2016. Modern Approaches to Segmentation of Tourist Market against Economic Instability. Azimyth of Scientific Researches: Economics and Management. Vol. 5, No. 1(14), 18-22.

Kayumova, G., Sheymardanov, S., Akhtarieva, R., \& Zhundibayeva, A. 2019. Developing creative potential of a schoolchild by means of native language. Journal of Social Studies Education Research, 10(1), 81-92.

Korableva, O. N., Kalimullina, O. V., Zaytseva, A. A., \& Larionov, A. I. 2018. Elaboration of database for the subject domain of innovation and economic growth potential. Paper presented at the Proceedings of the 31st International Business Information Management Association Conference, IBIMA 2018: Innovation Management and Education Excellence through Vision 2020, 6065-6073.

Kozhokin, E.M. \& Zherelina, O.N. 2017. The nation at the change of epochs. Russian state and society at the turn of the XX century. Giornale di Storia Costituzionale, 33(1), 67-80.

Kuznetsov, V.S. \& Suprun, I.K. 2017. Reduction of an adverse impact during well drilling by means of drilling waste usage. Journal of Ecological Engineering, 18(2), 12-15, doi:10.12911/22998993/68211.

Kuznetsov, V.S., Suprun, I.K. \& Petrov, D.S. 2017. Assessment and reduction of drilling waste impact on the environment components. Neftyanoe Khozyaystvo - Oil Industry, (1), 94-95.

Koptev, V.Y. \& Kopteva, A.V. 2017. Structure of energy consumption and improving openpit dump truck efficiency. Paper presented at the IOP Conference Series: Earth and Environmental Science, 87(2), doi:10.1088/1755-1315/87/2/022010.

Koptev, V.Y. \& Kopteva, A.V. 2018. Improving pit vehicle ecology safety. Paper presented at the Journal of Physics: Conference Series, 1015(5) 16DUMMY, doi:10.1088/1742-6596/1015/5/052014.

Korolyov, I.A., Lavrenko, S.A. 2017. Technological features of the interaction between a flexible traction element and extracting unit during the development of solid mineral resources of the seabed. International Journal of Applied Engineering Research, 12(9), 2031-2037

Korobov, G. \& Podoprigora, D. 2018. Depth computation for the onset of organic sedimentation formation in the oil producing well as exemplified by the sibirskoye oil field. Acta Technica CSAV (Ceskoslovensk Akademie Ved), 63(3), 481-492.

Korobov, G. \& Raupov, I. 2017. Study of adsorption and desorption of asphaltene sediments inhibitor in the bottomhole formation zone. International Journal of Applied Engineering Research, 12(2), 267-272.

Korchevenkov, S. \& Aleksandrova, T. 2018. Investigation of the influence a morphologic characteristic of the noble metal particles on gravity efficiency devices. Paper 
presented at the International Multidisciplinary Scientific GeoConference Surveying Geology and Mining Ecology Management, SGEM, 18(1.4) 99-104, doi:10.5593/sgem2018/1.4/S04.013.

Lavrenko, S.A., Shishljannikov, D.I., Maksimov, A.B. 2019. Energy efficient unit executive body for tunneling and cleaning operations. Innovation-Based Development of the Mineral Resources Sector: Challenges and Prospects - 11th conference of the Russian-German Raw Materials, 287-292.

Malarev, V.I., Kopteva, A.V. \& Nogtev, R.A. 2018. Electric drive simulation for drilling machine spinner. Paper presented at the IOP Conference Series: Earth and Environmental Science, 194(5), doi:10.1088/1755-1315/194/5/052012.

Malarev, V.I., Kopteva, A.V. \& Koptev, V.Y. 2019. Electric power supply system development for down-hole electric steam generators to produce high-viscosity oil. Paper presented at the 2018 International Multi-Conference on Industrial Engineering and Modern Technologies, FarEastCon 2018, doi:10.1109/FarEastCon.2018.8602954.

Melnikov, A.B., Shcherbakov, P.A., Voronkova, O.Y., Mikhaylushkin, P.V. \& Poltarykhin, A.L. 2018. Level of development of milk and dairy products market of the federal districts of the russian federation. International Journal of Mechanical Engineering and Technology, 9(10), 1214-1219.

Movchan, I.B., Yakovleva, A.A. 2017. Experience of qualitative and quantitative interpretation of nonpotential geofields with surface and deep morphostructural reconstructions on the example of unica ore province (Kareljya, Russia). International Journal of Mechanical Engineering and Technology, 8(12), 926-932.

Nefedov, Y. 2018. The arctic shelf and hard to recover oil reserves as alternative development of russian resource base. Paper presented at the Saint Petersburg 2018: Innovations in Geosciences.

Nefedov, Y.V. \& Klepikov, I.V. 2018. Occurrence regularities of nitrogen defects in the ural type crystal diamonds from different regions, doi:10.4028/www.scientific.net/KEM.769.201

Nefyodova, E.N. 2017. Segmentation of Tourist Market as a Factor of Improvement of a Tourist Company Competitiveness. Theory and Practice of Modern Scholarly Knowledge. Problems. Forecasts. Solutions: Digest of Scholarly Articles in Follow up of International Scientific and Practical Conference. SPb, 142-145.

Nikolaeva, N.V., Aleksandrova, T.N. \& Elbendari, A.M. 2018. Ore strength property evaluation in the design of ore preparation cycles. Paper presented at the Geomechanics and Geodynamics of Rock Masses, 1, 333-338.

Nikolaeva, N., Aleksandrova, T., Romashev, A. 2018. Effect of grinding on the fractional composition of polymineral laminated bituminous shales. Mineral Processing and Extractive Metallurgy Review, Volume 39, Issue 4, Pages 231-234, DOI: 10.1080/08827508.2017.1415207.

Ovcharenko, Y.V., Gumerov, R.R., Bazyrov, I.S., Kunakova, A.M., Mardashov, D.V., Gunkin, A.S. \& Legkokonets, V.A. 2017. Well killing specifics in conditions of fractured and porous carbonate reservoirs of the eastern part of the orenburgskoye oil-gas-condensate field. Neftyanoe Khozyaystvo - Oil Industry (12), 52-55.

Polyakova, A.G., Akhmetshin, E.M., Goloshchapova, L.V., Rakhmeeva, I.I., Noeva, E.E. \& Rakovskiy, V.I. 2018. A model of regional economic space modernization. European Research Studies Journal, 21, (Special Issue 2), 624-634.

Polyakova, A.G., Loginov, M.P., Serebrennikova, A.I. \& Thalassinos, E.I. 2019. Design of a socio-economic processes monitoring system based on network analysis and big 
data. International Journal of Economics and Business Administration, 7(1), 130139.

Poltarykhin, A.L., Suray, N.M., Zemskov, Y.V., Abramov, Y.V. \& Glotko, A.V. 2018. Food safety in the russian federation, its problems with the solutions. Academy of Strategic Management Journal, 17(4).

Podoprigora, D. \& Korobov, G. 2017. Selection of the acidizing compositions for use in terrigenous reservoirs with high carbonate content. International Journal of Applied Engineering Research, 12(2), 249-255.

Podoprigora, D. \& Raupov, I. 2018. Research of the influence of polymeric drilling mud on the filtration-capacitive properties of polymictic sandstones. Acta Technica CSAV (Ceskoslovensk Akademie Ved), 63(4), 537-546.

Podoprigora, D. \& Saychenko, L. 2017. Development of acid composition for bottom-hole formation zone treatment at high reservoir temperatures. Espacios, 38(48).

Podoprigora, D.G., Shangaraeva, L.A., Usenkov, A.V. \& Ilyushin, P.Y. 2016. Development of acid composition for bottom-hole formation zone treatment at high reservoir temperatures. Neftyanoe Khozyaystvo - Oil Industry, (4), 122-124.

Prischepa, O.M. \& Grokhotov, E.I. 2018. GM18-084 specification of the regional structural model of the northern timan-pechora, including the pechora sea. Paper presented at the Geomodel 2018 - 20th Conference on Oil and Gas Geological Exploration and Development, doi:10.3997/2214-4609.201802379.

Prischepa, O., Bogatsky, V., Chumakova, O., Shaburova, M. \& Kuranov, A. 2018a. Improving of geological petroleum zoning of the northern timan-pechora province. Paper presented at the Saint Petersburg 2018: Innovations in Geosciences.

Prischepa, O., Chumakova, O., Zemlyakov, A., Orlova, L. \& Blinkova, E. 2018 b. Assessment of petroleum exploration activity performed in the timan-pechora petroleum province. Paper presented at the Saint Petersburg 2018: Innovations in Geosciences.

Prischepa, O., Grokhotov, E., Makarova, I., Averyanova, O. \& Nikiforova, V. 2018c. Petroleum prospects of the domanik formation in timano-pechora province. Paper presented at the Saint Petersburg 2018: Innovations in Geosciences.

Prischepa, O.M. \& Averyanova, O.Y. 2017. Approaches to the hydrocarbon potential evaluation of the shale strata, domanik deposits of timan-pechora province. Paper presented at the EAGE/SPE Joint Workshop on Shale Science 2017: Prospecting and Development.

Raupov, I. \& Podoprigora, D. 2017. Laboratory researches of the polymeric composition in the pore space of bulk models. International Journal of Applied Engineering Research, 12(3), 365-371.

Raupov, I.R. \& Korobov, G.Y. 2018. Research of polymer compositions rheological properties for oil production. Acta Technica CSAV (Ceskoslovensk Akademie Ved), 63(3), 493-500.

Resilience of tourism development. URL: http://www2.unwto.org/ (date of application: 15.02.2019).

Safieva, R.Z., Stavitskaya, A.V., Safieva, E.O. \& Aleksandrova, T.N. 2017. Hydrogenation of unsaturated hydrocarbons on pt and pd catalysts encapsulated in mesoporous bakelites. Chemistry and Technology of Fuels and Oils, 53(4), 455-463, doi:10.1007/s10553-017-0823-5.

Sarafanova, E.V., Yaczuk, A.V. 2009. Marketing in Tourism. M: Nauch. kn., 565 p.

Shagiakhmetov, A., Tananykhin, D., Terleev, A. 2018. Development of water-shutoff composition based on carboxymethyl cellulose for fractured and fractured-porous 
oil and gas reservoirs. Acta Technica CSAV (Ceskoslovensk Akademie Ved), 63 (3), 475-480.

Sharifov, A.R. \& Mardashov, D.V. 2018. Liquid solvent addition to steam for enhancing recovery of heavy oil with cyclic steam stimulation. Paper presented at the Saint Petersburg 2018: Innovations in Geosciences.

Solnyshkina, M.I., Harkova, E.V. \& Kiselnikov, A.S. 2014. Unified (russian) state exam in english: Reading comprehension tasks. English Language Teaching, 7(12), 1-11, doi:10.5539/elt.v7n12p1.

Solnyshkina, M.I., Solovova, E.N., Harkova, E.V. \& Kiselnikov, A.S. 2016. Language assessment course: Structure, delivery and learning outcomes. International Journal of Environmental and Science Education, 11(6), 1223-1229, doi:10.12973/ijese.2016.392a.

Sozinova, A.A., Okhrimenko, O.I., Goloshchapova, L.V., Kolpak, E.P., Golovanova, N.B. \& Tikhomirov, E.A. 2017. Industrial and innovation clusters: Development in Russia. International Journal of Applied Business and Economic Research, 15(11), 111-118.

Sultanova, D. \& Mardashov, D. 2016. Research of the effect of scale inhibitors on the effectiveness of corrosion inhibitors in oil wells. International Journal of Applied Engineering Research, 11(18), 9460-9463.

Tananykhin, D., Tcvetkov, P., Kamoza, V. 2018. Analysis and Recommendations of Sand Consolidation Methods to Limit Sand Production in Gas Wells. Journal of Physics: Conf. Series, 1072, 012022, doi :10.1088/1742-6596/1072/1/012022.

Tananykhin, D., Saychenko, L. 2017. Sand control methods for the development of oil \& gas fields with hard to recover reserves. Espacios, 38(48), 31.

Tananykhin, D.S., Shagiakhmetov, A.M. 2016. Justification of technology and fluids for treatment of the unconsolidated carbonate reservoirs. International Journal of Applied Engineering Research, 11(1), 744-748.

Tcvetkov, P., Pritulyak, D., Tananykhin, D. 2018. Comparison of the Multi-Directional Delivery Efficiency of Low-Tonnage LNG and Pipeline Gas in Russia. Journal of Physics: Conf. Series, 1072, 012021, doi :10.1088/1742-6596/1072/1/012021.

Tananykhin, D., Khusainov, R. 2016. Diffusion of nonionic surfactants diffusion from aqueous solutions into viscous oil. Petroleum Science and Technology, 34(24), 1984-1988, doi: 10.1080/10916466.2016.1233245.

Takhumova, O.V., Kasatkina, E.V., Maslihova, E.A., Yumashev, A.V. \& Yumasheva, M.V. 2018. The main directions of increasing the investment attractiveness of the Russian regions in the conditions of institutional transformations. Espacios, 39(37).

Trufanova, I.S., Lavrenko, S.A. 2016. Elaboration of the mathematical model of the intermediate linear drive belt with pressure rollers. ARPN Journal of Engineering and Applied Sciences, 11(19), 11581-11583.

Vasiliev, B.U. \& Mardashov, D.V. 2017. Methods and tools for education and research in the information society. Paper presented at the Proceedings of the 2017 International Conference "Quality Management, Transport and Information Security, Information Technologies", IT and QM and IS 2017, 699-703, doi:10.1109/ITMQIS.2017.8085920.

Yankevich, V.S. 2005. Marketing in Hospitality Industry and Tourism: Russian and Russian and International Experience. M.: Finansy` i statistika. 415 p.

Yamova, O.V., Maramygin, M.S., Sharova, I.V., Nesterenko, J.N., Sobina, N.V. 2018. Integral Valuation of an Enterprise's Competitiveness in the Industrial Economy. European Research Studies Journal, 21, (Special Issue 2), 777-787. 